\title{
Szkice
}

\section{Doświadczenie i różnica. Status przedmiotu badań i tożsamość badaczy w studiach o niepełnosprawności}

Klaudia Muca

TEKSTY DRUGIE 2020, NR 2, S. 13-29

DOI: 10.18318/td.2020.2.2 | 0000-0001-5833-0334

Dytanie o status przedmiotu badań, czyli o jego ist1 niejące definicje, sposób określania jego miejsca w sferze publicznej, kulturze czy nauce, jego reprezentacje i związane $\mathrm{z}$ nim sfery pozbawione reprezentacji (ukryte, tabuizowane, przemilczane), oraz o inne kwestie determinujące konteksty dla przedmiotu badań wydaje się jednym z podstawowych pytań inicjujących działanie badawcze o charakterze krytycznym. Nie chodzi przy tym jednak tylko o genetyczną analizę pojęć, lecz także o sposób ich używania w realizowaniu badań, którym przypisane zostaje doniosłe znaczenie społeczne i polityczne: badań polegających na odkryciu zakrytego, odpomnieniu zapomnianego, przywróceniu jakiegoś tematu historii czy „odzyskaniu obecności”".

1 Cytowane sformułowanie nawiązuje do książki: Odzyskiwanie obecności. Niepełnosprawność w teatrze i performansie, red. E. Godlewska-Byliniak, J. Lipko-Konieczna, Fundacja Teatr 21, Warszawa 2017. Jednym z celów tej publikacji - jak czytamy we wstępie zatytułowanym Otwieranie pola - jest wprowadzenie do studiów o niepełnosprawności oraz analiza obecności osób z niepełnosprawnościami $w$ teatrze i przestrzeni sztuk performatywnych.
Klaudia Muca - mgr, doktorantka w Katedrze Antropologii Literatury i Badań Kulturowych WP Uj; zainteresowania naukowe: studia o niepełnosprawności, literatura najnowsza, krytyka i teoria literatury; jest redaktorką monograficznego numeru "Fragile" o niepełnosprawności (2017) oraz autorką książki Poiesis doświadczenia, poiesis tożsamości. Narracje o afazji (2019). Kontakt: klaudia.muca23@ gmail.com. 
Studia o niepełnosprawności (disability studies), które są podstawowym kontekstem dla tego artykułu, a także jego przedmiotem, realizują opisane wyżej w dość zawoalowany sposób cele rewizji i krytyki istniejącego status quo we wszystkich możliwych obszarach aktywności ludzkiej, w których pojawiają się jakaś nierówność, umniejszenie pozycji, ograniczenie dostępności, wykluczenie, segregacja, dyskryminacja lub konsekwentne działanie zmierzające do tego, by trwale odseparować jakieś grupy ludzi od innych grup. Określanie przedmiotu badań w tym kontekście oznacza więc - w skrócie i w bardzo ogólnym ujęciu - wskazanie przestrzeni, w której pojawia się nierówność, a kolejne etapy badań polegają na analizie etiologii tej nierówności i tworzeniu naukowej reprezentacji tej analizy. Badania artystycznych przedstawień niepełnosprawności ze względu na swój przedmiot przyjmują oczywiście inne schematy analizy.

Celem tych wstępnych rozważań nie jest jednak opracowanie narracji na temat metodyki postępowania badawczego w kontekście niepełnosprawności, tylko zwrócenie uwagi na znaczenie w działaniu naukowym okoliczności i uwarunkowań, które wiążą przedmiot badań i badacza, przedmiot i metodę, narrację naukową i biograficzną, doświadczenie i jego reprezentację (także przedstawioną w tekście naukowym), komplikując jasne, oparte na różnicy porządkowanie pozycji podmiotów zaangażowanych w proces badawczy.

Niepełnosprawność (disability) w dyskursie nauk humanistycznych, zwłaszcza w interdyscyplinarnych studiach kulturowych, funkcjonuje jako pojęcie nomadyczne ${ }^{2}$, któremu można przypisać wiele różnych, badawczo umotywowanych kategorii - jedną z nich jest kategoria doświadczenia niepełnosprawności. Chciałabym skupić się właśnie na powstającej w ten sposób kategorii badawczej „doświadczenia niepełnosprawności” i implikacjach jej użycia w powiązaniu (albo w konfrontacji) z kwestią problematyzowania i oceniania tożsamości badacza pod względem obecności lub nieobecności doświadczenia niepełnosprawności w jego biografii. Ten tekst łączy więc elementy namysłu nad wybranymi zagadnieniami z zakresu tożsamości dyscypliny oraz jej słownika, nad własną pozycją badawczą i jej projektowaniem, a także nad doświadczeniem i różnicą jako

2 Pojęcia nomadyczne są pojęciami, które „uzyskały zdolność przemieszczania się z jednego dyskursu naukowego do innego, dzięki zacieraniu się granic między dyscyplinami, które jest historycznym przywilejem współczesnej nauki". Są one częścią pewnego stanowiska epistemologicznego, które ujmuje zjawiska i kategorie w ścisłym powiązaniu kontekstu, w jakim występują, i uwarunkowań dyskursywnych, jakim polegają. Zob. R. Briadotti Poprzez nomadyzm, "Teksty Drugie" 2017 nr 6 (108), s. 118. 
jednymi z podstawowych pojęć w krytyczno-emancypacyjnym projekcie studiów o niepełnosprawności.

\section{Przymus badawczej autorefleksji jako element wychowawczy}

Badawcza (samo)identyfikacja jako reprezentanta danej dziedziny badań wymaga zazwyczaj jakiegoś komentarza wyjaśniającego motywacje i pokazującego walor innowacyjny pomysłów, jakie chce się w obrębie danej dyscypliny i po uprzednim przypisaniu (się) do niej realizować. W przypadku młodych badaczy realizujących interdyscyplinarne projekty w obszarach badawczych o krytyczno-emancypacyjnym nastawieniu ta samoidentyfikacja przybiera niekiedy formę przymusu, to znaczy od badacza wymaga się opisania własnej pozycji, postawienia wyjściowej diagnozy motywacji i stopnia zaangażowania na rzecz przedmiotu badań. Ten przymus nie jest jednak jakimś rodzajem opresji stosowanej przez starszych badaczy po to, by zdyscyplinować młodszych; kryterium wieku - jak się wydaje - nie ma tu aż tak doniosłego znaczenia jak kryterium doświadczenia w praktykowaniu krytyczno-emancypacyjnych działań badawczych (oba te kryteria oczywiście mogą iść w parze, ale nie muszą). Możliwe efekty stosowania tego przymusu nie w celu dyscyplinowania, tylko w celach wychowawczych i poznawczo-emancypacyjnych przedstawiam poniżej na konkretnym przykładzie z własnego doświadczenia.

We wrześniu 2019 roku uczestniczyłam w Kolonii w szkole doktorskiej pod nazwą "7th disABILITY MUNDUS doctoral school: «(Self)Representing disABILITY»", poprzedzającej trzydniową konferencję organizowaną przez ALTER European Society for Disability Research - jednostkę badawczą zajmującą się badaniami nad niepełnosprawnością. Ostatniego dnia szkoły polecono nam wykonać ćwiczenie polegające na określeniu najważniejszych obszarów, w jakich realizujemy swoje badania jako doktoranci, podstawowych przedmiotów badań, metod i metodologii oraz - co wydało mi się znamienne - na określeniu własnej pozycji na powstałej w ten sposób mapie obszarów naukowego zaangażowania i wpływu. Na swoim wykresie, nazwanym Grafem planetarnym, starałam się sproblematyzować realizowanie badań o charakterze krytyczno-emancypacyjnym w pozycji pomiędzy pewnymi dziedzinami badawczymi, przedstawionymi jako oddziałujące na siebie planety. Tymi dziedzinami były studia literaturoznawcze, badania niepełnosprawności (disability studies), studia kulturowe jako ogólna perspektywa krytyczna, studia nad dziedzictwem i kulturą materialną. "Ja" badacza 
na tym grafie funkcjonuje jako satelita krążący pomiędzy tymi „planetami”, pozostający w ich strefie wpływów i jednocześnie wewnątrz pewniej orbity określającej przedmioty badań; na tej orbicie znajdowały się: reprezentacja, doświadczenie, mniejszość, narracja, tekst jako obiekt materialny, zaangażowanie. W planetarnym układzie z zaznaczonymi dziedzinami, w których polu prowadzone są badania, przedmiotami badań, elementami metodologii oraz pozycjami badacza, podkreślona zostaje zależność wszystkich wymienionych elementów, mechanika wzajemnego oddziaływania, przyciągania oraz funkcjonowania pomiędzy, zawsze w odniesieniu do innej dziedziny (innej "planety").

Opisane ćwiczenie ilustruje pewien mechanizm wychowawczy, który w tytule tego podrozdziału nazwałam przymusem autorefleksji, kładąc nacisk na narrację o pozycji młodego badacza, rozpoczynającego naukową aktywność o charakterze krytyczno-emancypacyjnym w obrębie kilku uzupełniających się dziedzin badawczych (planetarny układ dziedzin). Ten mechanizm jest charakterystyczny ogólnie dla studiów kulturowych - wielowymiarowego, wielotematycznego i wielonurtowego paradygmatu uprawiania studiów humanistycznych w XX i XXI wieku. Można określić go jako nieopresyjny przymus, którego celem jest zaprojektowanie aktywności naukowych tak, by uwzględniały analizy postaw i tożsamości podejmujących te aktywności badaczek i badaczy. Ten ogólny cel realizuje się oczywiście poprzez cele pośrednie, do których należą: po pierwsze, budowanie z przedmiotem badań relacji warunkującej zaangażowanie na rzecz tego przedmiotu jako postawę konieczną do przeprowadzenia badań o charakterze poznawczym i krytyczno-emancypacyjnym; po drugie, zwrócenie uwagi na role podmiotowe w procesie badawczym oraz na kontekst biograficzny (związany z doświadczeniem/aniem niepełnosprawności w przypadku disability studies); po trzecie, refleksję na temat sytuacji, w której przedmiot badań nie jest $\mathrm{z} n$ a ny - z - wła s n e go - d ośw i a c z e n i a ${ }^{3}$ i w związku z tym może powodować przeszkody w realizacji pewnych strategii krytyczno-emancypacyjnych (jedną z nich analizuję w drugim podrozdziale na przykładzie projektowania postawy badawczej przez Elizabeth Barnes, amerykańską filozofkę i badaczkę niepełnosprawności).

3 Kategorie znany-z-własnego-doświadczenia oraz nieznany-z-własnego- d o ś wi a d c z e n i a traktuję jako dwie kategorie dyskursywne potrzebne do przeprowadzenia wywodu na temat roli doświadczenia niepełnosprawności jako przedmiotu badań oraz jako elementu tożsamości badacza w studiach o niepełnosprawności - stąd wyróżniająca te kategorie forma zapisu. 
Nieprzypadkowo opisane na początku niniejszego podrozdziału autorefleksyjne ćwiczenie pojawiło się jako zwieńczenie trwających w trakcie trzydniowej szkoły doktorskiej rozmów na temat reprezentacji doświadczenia niepełnosprawności, kategorii „siebie” (self) jako jednej z podstawowych we współczesnych badaniach kulturowych o charakterze emancypacyjnym oraz pozycji i zainteresowań badawczych uczestniczek i uczestników szkoły. Refleksja na temat tożsamości badawczej oraz pozycji badaczki i badacza wobec „przedmiotu” badań do tej pory pojawiała się - niczym sowa Minerwy wylatująca o zmierzchu - zazwyczaj jako podsumowanie lub zwieńczenie pewnego procesu, nie jako element przygotowania projektu badawczego poprzedzający badania. Tego typu praktyka mogłaby sugerować, że określenie własnej pozycji jako badaczki i badacza wymaga retroaktywnej refleksji już po zakończeniu badań, co również mogłoby potwierdzać pewne intuicyjne rozpoznania, że - po pierwsze - dopiero realizując badania, stajemy się badaczami i dopiero po ich przeprowadzeniu jesteśmy w stanie zająć jakąś pozycję wobec przedmiotu badań oraz że - po drugie - refleksja o tożsamości wymaga uzyskania naukowego rezultatu i upowszechnienia go wtedy pozycja badawcza jest legitymizowana nie tylko przez deklaratywne samookreślenie, lecz również przez nieodzowny dla nauki wymierny efekt pracy badawczej.

Jednak w przypadku aktywności naukowych młodych badaczek i badaczy większy nacisk w procesie wychowawczym kładzie się, jak sądzę, na projektowanie badań jako dyskursywnej ramy, prezentowanej i prezentującej się jako innowacyjna i interdyscyplinarna - ramy, która odnosi się do doświadczenia jako pewnej formy realności uobecnionej w procesie badawczym. Doświadczenie jest opisywane i reprezentowane, staje się przedmiotem badań podlegającym - w przypadku badań krytycznych i emancypacyjnych - subwersywnemu procesowi „odprzedmiotowienia”, innymi słowy - powiązania z konkretną sytuacją społeczno-polityczną i jej istniejącymi reprezentacjami. Ten proces, powiązany z nieopresyjnym przymusem autorefleksji badawczej, jest dostrzegalny bardzo wyraźnie w polu kulturowych studiów o niepełnosprawności w sytuacji egzystencjalno-zawodowej badaczy, którym niepełnosprawność jest (tymczasowo) ni e znana - z - wła s n e go - d o świ a d c z e $n$ i a. Niepełnosprawność (a raczej doświadczenie niepełnosprawności) nie jest elementem ich codzienności (sytuacja egzystencjalna), jest „przedmiotem" badań (sytuacja zawodowa) - tak w skrócie można ująć sytuację pełnosprawnych badaczy niepełnosprawności. Ten skrót jednak wymaga wielu dopowiedzeń i wyjaśnień; w tak przedstawionej formie może być 
odebrany jako wstęp do prezentacji antagonizmu opartego na obecności lub nieobecności niepełnosprawności, co nie jest oczywiście celem tego artykułu. Interesuje mnie egzystencjalna dychotomia niepełnosprawny/ pełnosprawny badacz, która faktycznie różnicuje pole badań o niepełnosprawności, jednak nie powinna stanowić sposobu na odróżnienie, to znaczy oddzielenie, absolutyzowanie różnicy, antagonizowanie, biegunowe przeciwstawienie - wszystkie wymienione kategorie synonimiczne nie są pożądanymi postawami wobec doświadczenia niepełnosprawności w badaniach o charakterze krytyczno-emancypacyjnym ze względu na fakt, że należą do uznawanego za opresyjny upowszechnianego systemu społecznego urządzenia, w którym sprawność waloryzowana jest pozytywnie, a niepełnosprawność - negatywnie.

Ponadto refleksja na temat pozycji (badawczej) wobec doświadczenia jest stałym elementem w nieco szerszym obszarze badań nad doświadczeniem - chodzi o badania tak zwanych doświadczeń granicznych, takich jak traumy wojenne, Zagłada czy choroba śmiertelna. Przedstawione w tym artykule rozważania chciałabym włączyć w nurt krytycznej refleksji nad możliwościami opisania i uobecnienia doświadczenia, refleksji, która w dość bezpośredni sposób pokazuje, że pisanie o czyimś doświadczeniu nie musi rozwijać się w aurze niewiary w możliwość reprezentacji oraz w porozumienie budowane na podstawie właśnie tego doświadczenia ${ }^{4}$. Różnica, jaka pojawia się w trakcie pisania (np. różnica egzystencjalna, polegająca na tym, że nie brało się udziału w wojnie), jest tymczasowym miejscem wspólnym, w którym zachodzi jednocześnie proces przedstawiania doświadczenia i jego rozumienia. Poza tym miejscem, gdy pod pewnymi warunkami zostanie ono opuszczone - jak pokazuje między innymi aktywność Elizabeth Barnes, bohaterki kolejnego podrozdziału - różnicę zastępuje narracja o podobieństwie, pozytywnie afirmująca i w ten sposób znosząca podziały związane z oczywistą, na przykład fizyczną, odmiennością. Pierwszym krokiem na drodze do adekwatnego przedstawienia okazuje się przepracowanie różnicy i konstruujących ją przekonań, na co uwagę zwracają redaktorki broszury O osobach z niepetnosprawnościami - aktywistki i badaczki związane z Fundacją

4 Jednym z przykładów publikacji, która wpisuje się w ten nurt krytyczny wobec aksjomatu niewyrażalności doświadczeń granicznych, jest książka Jacka Leociaka Doświadczenia graniczne. Studia o dwudziestowiecznych formach reprezentacji (Wydawnictwo Instytutu Badań Literackich PAN, Warszawa 2018). We Wprowadzeniu do książki autor stwierdza, że przekonanie o niewyrażalności doświadczeń granicznych jest podważane przez empiryczny fakt mnogości prób ich przedstawienia (s. 9). 
Humanity in Action Polska ${ }^{5}$. Wspomniana broszurka to w gruncie rzeczy zeszyt ćwiczeń do niepełnosprawności, wymagający od odbiorcy, by zwrócił uwagę na to, co nas - ludzi - od siebie różni (np. stopień sprawności) oraz jakie różnice występują wśród społeczności osób z niepełnosprawnościami. Broszurkę kończy rozdział o aktywizmie i zaangażowaniu na rzecz afirmacji odmienności. W tej publikacji doświadczenie niepełnosprawności rozpoznaje się poprzez różnicę, która prowadzi do odkrycia odrębnego egzystencjalnego doświadczenia niesprowadzalnego tylko i wyłącznie do niepełnosprawności. Poza różnicą jako tymczasowym miejscem wspólnym istnieje więc miejsce dla aktywistycznego działania, które z analizy różnic czyni narzędzie emancypacji doświadczenia.

\section{Manifestowanie doświadczenia i pozycji badawczej jako działanie krytyczno- emancypacyjne (przypadek Elizabeth Barnes)}

W anglojęzycznej literaturze przedmiotu takie zagadnienia, jak relacje między niepełnosprawnymi i pełnosprawnymi badaczami, uniwersalne projektowanie badań oraz przestrzeni do badań ${ }^{6}$, zwrócenie uwagi na struktury hierarchiczne narzucane przez określone metodologie (metodologia nierelacyj$\mathrm{na}^{7}$ ), stanowią istotny element disability studies jako dyscypliny wyrastającej z aktywizmu na rzecz osób z niepełnosprawnościami. W polskiej literaturze przedmiotu - jak wynika z moich dotychczasowych doświadczeń i lektur refleksja o charakterze metodologicznym i zwrócona na pozycje badaczy oraz egzystencjalne „uwarunkowania” jest słabo obecna, przy czym stwierdzenie to odnosi się do pola kulturowych studiów o niepełnosprawności, a nie badań dotyczących niepełnosprawności w ogóle. Gest manifestacji własnej

5 O osobach z niepełnosprawnościami, red. S. Varga, M. Szarota, M. Mazur-Rafał, Fundacja Humanity in Action Polska, Warszawa 2019.

6 Projektowanie uniwersalne kojarzy się raczej z projektowaniem przestrzeni, w której miałyby poruszać się osoby z różnymi rodzajami niepełnosprawności. Okazuje się jednak, że postulat uniwersalności stosuje się również w odniesieniu do projektowania przebiegu procesu badawczego po to, by uczynić ten proces oraz jego rezultaty bardziej dostępnymi. Zob. np. A.S. Williams, S.M. Moore Universal design of research: inclusion of persons with disabilities in mainstream biomedical studies , "Science Translational Medicine" $2011 \mathrm{nr} 3$ (82), https://stm.sciencemag. org/content/3/82/82cm12.full (dostęp: 02.01.2020).

7 C. Tregaskis, D. Goodley Disability Research by Disabled and Non-Disabled People:Towards a Relational Methodology of Research Production, "International Journal of Social Research Methodology" $2005 \mathrm{nr} 8$ (5), 363-374. 
pozycji badawczej - pozycji wobec doświadczenia niepełnosprawności - jest istotnym elementem disability studies na Zachodzie, jedną z podstawowych cech tych studiów. To nie tylko egzystencjalny przypis do prowadzonych badań, lecz bardzo ważny znak emancypacji doświadczenia (niepełnosprawni badacze) i/lub postawy opowiedzenia się po stronie doświadczenia niepełnosprawności (pełnosprawni badacze), stanowiący mocną podstawę realizowanego projektu naukowego, zakorzeniającą badania w konkretnej rzeczywistości społecznej, politycznej i kulturowej.

Przykładem manifestacji własnej pozycji badawczej chciałabym uczynić fragmenty wstępu Elizabeth Barnes do jej książki The Minority Body. A Theory of Disability (2016). Wybrałam tę książkę (ten projekt badawczy) nie tylko ze względu na to, że Barnes jest osobą z niepełnosprawnością - niepełnosprawność jest więc jej z n an a - z - wła s n e g o - d o św i a d c zenia. Jest też filozofką różnicy, badaczką eksplorującą i eksponującą znaczenie realnej i absolutyzowanej różnicy, która ustanawia pozycje i porządkuje przestrzenie ludzkiej aktywności. Wstęp do The Minority Body ${ }^{8}$ jest manifestem sprzeciwu wobec nauki, która uprzedmiatawia, a czasami nawet eliminuje doświadczenie egzystencjalne jako motywację badań, ich uzasadnienie i bardzo ważny element, stanowiący brakujące ogniwo pośredniczące między życiem a nauką.

Istotnym momentem krytycznym w przedmowie oraz wstępie do książki Barnes - pojawiającym się także w wielu innych projektach naukowych, których rezultaty w formie książek są poprzedzone albo wstępami-manifestami dotyczącymi doświadczenia niepełnosprawności, albo wypowiedziami towarzyszącymi w formie na przykład wywiadów - jest dostrzeżenie pewnej antynomii między osobistym doświadczeniem a możliwością uczynienia z niego przedmiotu badań, ściślej: przedmiotu filozoficznego namysłu, a następnie dostrzeżenie absurdalności takiego antynomicznego sposobu myślenia. Barnes pisze:

Myślałam do niedawna, że nie mogłabym rzetelnie filozofować o niepełnosprawności, bo temat jest tak bardzo osobisty. Ale to przecież absurd. Niepełnosprawność jest tematem, który jest osobisty dla każdego. Kiedy ostatni raz to sprawdzałam, większość pełnosprawnych ludzi była dość mocno osobiście zaangażowana w bycie pełnosprawnymi. Fakt, że tego

8 Tytułową kategorię minority body tłumaczę jako "ciało mniejszościowe”. Nie znam innych propozycji tłumaczeń; omawiana książka Barnes nie została jeszcze przetłumaczona na język polski. 
rodzaju osobiste zaangażowanie można niezwykle łatwo zignorować, jest jednym z bardziej zgubnych aspektów obsesji filozofii na punkcie obiektywnej neutralności. Bardzo łatwo pomylić perspektywę normalności (the view form normal) z patrzeniem znikąd (the view form nowhere). Potem tylko głosy mniejszościowe są tymi, które wyróżniamy jako stronnicze lub pozbawione obiektywności. Jeśli chodzi o niepełnosprawność, nie jestem obiektywna. I ty też nie jesteś. Niezależnie od tego, czy jesteś niepełnosprawny, czy (czasowo) sprawny. ${ }^{9}$

W tym krótkim fragmencie Barnes zwraca uwagę na kilka istotnych założeń filozofii, dokonuje ich rewizji, a następnie - po zrewidowaniu - wykorzystuje przy projektowaniu bardziej systematycznej (naukowej) refleksji na temat niepełnosprawności.

Po pierwsze, badaczka krytykuje aksjomat dyscypliny, którą reprezentuje - filozoficzny aksjomat obiektywności i neutralności pozwalający jakoby zbudować uniwersalną wiedzę o człowieku i jego relacjach ze światem. Warto zwrócić uwagę, że Barnes mówi o tym aksjomacie jako o obsesji, o dążeniu do neutralności jako szkodliwym aspekcie filozofii. Jej krytyka dotyczy neutralności filozofii nie w kontekście politycznym, lecz raczej w egzystencjalnym, dla którego podstawową kategorią jest to, co osobiste, na przykład doświadczenie niepełnosprawności. Wyłączenie tego, co osobiste, z obszaru badań wiąże opisany aksjomat filozofii analitycznej z obiektywizacją i uprzedmiotowieniem niepełnoprawności w medycynie. Wątek medyczny i medycznego modelu niepełnosprawności pojawia się w przedmowie Barnes tuż po cytowanym wyżej akapicie; autorka podaje ogólne informacje na temat tego, że poddawana była różnego rodzaju operacjom, spotykała ludzi z rzadkimi schorzeniami, musiała borykać się z niewiedzą na temat swojego stanu zdrowia (niepotwierdzające się diagnozy lekarzy). Ten fragment badaczka podsumowuje w następujący sposób: „W skrócie moje doświadczenie niepełnosprawności było skrajnie

9 E. Barnes The minority body. A theory of disability, Oxford University Press, Oxford, 2016, s. IX. Tłum. własne za: "I used to think I couldn’t philosophize about disability precisely because the topic is so personal. But on reflection, that's absurd. Disability is a topic that's personal for everyone. The last time I checked, most non-disabled people are pretty personally invested in being non-disabled. The fact that this sort of personal investment is so easy to ignore is one of the more pernicious aspects of philosophy's obsession with objective neutrality. It's easy to confuse the view from normal with the view from nowhere. And then it's uniquely the minority voices which we single out as biased or lacking objectivity. When it comes to disability, I'm not objective. And neither are you. And that's true whether you're disabled or (temporarily) non-disabled". 
zmedykalizowane"10. W tych kontekstach - filozofii analitycznej, medycyny i osobistego doświadczenia niepełnosprawności - disability studies dowartościowują obecność doświadczenia w procesie badawczym (mniej lub bardziej sprofesjonalizowanym), rezerwując dla niego bardzo ważną funkcję pośrednika między aktywnością egzystencjalną (pozycja osoby z niepełnosprawnością) a aktywnością zawodową (pozycja badacza niepełnosprawności).

Po drugie, Barnes w cytowanym fragmencie dotyka kwestii pozycji badawczej konfrontując dwie perspektywy: perspektywę normalności (the view from normal) i patrzenie znikąd (the view form nowhere). Fragment, z którego pochodzą te dwie kategorie, brzmi: „Bardzo łatwo pomylić perspektywę normalności z perspektywą znikąd". Norma, spojrzenie z pozycji normalności, odnosi się w tym kontekście zarówno do stanu sprawności, jak i do „normy naukowej", która obejmuje obiektywność i neutralność badań. W systemie tworzenia wiedzy tym, co normalne, jest to, co jak najmniej osobiste, a jak najbardziej uniwersalne, to znaczy odnoszące się do jak największej liczby możliwych przypadków i możliwych doświadczeń. Barnes próbuje odwrócić ten porządek poprzez łączenie refleksji egzystencjalnej z pracą naukowo-badawczą odnoszącą się do (osobistego) doświadczenia niepełnosprawności. Systematyczna refleksja nad niepełnosprawnością służy więc nie tylko krytyce założeń dyskursów profesjonalnych (neutralność filozofii analitycznej, uprzedmiotowienie doświadczenia w medycynie), lecz także emancypacji doświadczenia. Podłożem studiów o niepełnosprawności jako nurtu nowoczesnych studiów kulturowych jest właśnie promowanie naukowego zaangażowania, które łączy profesjonalizm z osobistym doświadczeniem lub działaniem na rzecz tego doświadczenia w sytuacji, kiedy niepełnosprawność jest n i e z n an a - z - wła s n e go - d oświ a d c zenia. Doświadczenie - jeśli spojrzeć na rzecz z perspektywy filozofii nauki - staje się elementem metodologii disability studies, stanowiąc nie tylko punkt wyjścia do badań,lecz także jeden z ich głównych celów (w skrócie celem disability studies jest emancypacja doświadczenia niepełnosprawności), który można wymienić obok celów takich istotnych, jak upowszechnienie społecznego modelu niepełnosprawności, zbieranie danych na temat sytuacji osób z niepełnosprawnościami i reprezentacji ich doświadczeń w różnych epokach historycznych czy upodmiotowienie połączone z przypisaniem politycznej sprawczości (empowerment) ${ }^{11}$.

10 Tamże. Tłum. Własne za: „In short, my experience of disability was extremely medicalized”.

11 H. Mogran Working with disabled people, w: Applying Research Evidence in Social Work Practice, ed. M. Webber, Red Globe Press, London 2015, s. 185. 
Patrzenie znikąd jako kategoria wprowadzona przez Barnes do opisu relacji między perspektywami normalności, neutralności oraz doświadczenia służy krytycznej analizie dotychczasowych sposobów projektowania pozycji badawczej w studiach o niepełnosprawności, a zwłaszcza pozycji wobec „przedmiotu” badań. Wprowadzając do badań własne doświadczenie, autorka The Minority Body zwraca również uwagę na fakt, że grupy czy głosy mniejszościowe są często słabo obecne w procesie badawczym jako reprezentujące siebie i własne doświadczenie. Barnes powtarza w dużej mierze postulaty krytycznej zmiany perspektywy badań, jakie pojawiły się w latach 9o. XX wieku na Zachodzie w odniesieniu do nauk społecznych - chodzi oczywiście o zaprojektowanie i wprowadzenie paradygmatu badań emancypacyjnych (emancipatory research). Krytykę, która została wówczas sformułowana, zrekonstruuję krótko w kolejnym podrozdziale, skupiając się na doświadczeniu i różnicy w odniesieniu do pozycji badaczy pełnosprawnych. Ta krytyka jest stale obecna w polu studiów o niepełnosprawności nie tylko jako zbiór rewizyjnych koncepcji, lecz także jako pewnego rodzaju napomnienie i przestroga przez przechodzeniem do porządku dziennego nad tematami związanymi z tożsamością dyscypliny oraz nad praktyką badania doświadczenia niepełnosprawności.

\section{Pasożytnicza pozycja badawcza i konstruktywne kontemplowanie różnicy}

Konieczność zweryfikowania własnej pozycji jako badaczki lub badacza doświadczenia niepełnosprawności, określona wyżej jako nieopresyjny przymus wychowawczy stosowany wobec młodszych badaczy i badaczek (ale nie tylko) w badaniach kulturowych o charakterze interdyscyplinarnym, zapobiega zagrożeniom wynikającym z patrzenia znikąd. Weryfikacja pozycji i postawy w studiach o niepełnosprawności obejmuje bardzo często manifestację własnej niepełnosprawności (osoby z niepełnosprawnością, niepełnosprawni badacze ibadaczki) lub manifestację braku niepełnosprawności (osoby pełnosprawne, pełnosprawni badacze doświadczenia niepełnosprawności). Ta manifestacja - można ją roboczo nazwać manifestem autobiograficznym - jest istotnym elementem krytyczno-emancypacyjnej metody prowadzenia badań w obrębie disability studies. Kwestia doświadczenia niepełnosprawności jako elementu biografii badaczy oraz przedmiotu badań wprowadza rozróżnienie niepełnosprawnych i pełnosprawnych badaczy niepełnosprawności, badaczy, którym niepełnosprawność jako przeżycie egzystencjalne o społeczno-politycznych oraz kulturowych reprezentacjach 
jest znane-z-własnego-doświadczenia,i tych, którymjest nie zn a n e-z-wła s nego-d oświ a d c z e nia. Używam w tym kontekście wyrażenia „znane z doświadczenia”, żeby zwrócić uwagę na intuicyjnie wyczuwany w momencie mówienia dyskursywny mechanizm, który wprowadza do naszej wypowiedzi czy pracy badawczej pewną hierarchię. "Znane z doświadczenia" oznacza, że posiadamy jakąś wiedzę na dany temat lub o danym zjawisku, jest ono przez nas oswojone (należy bowiem do naszej biografii), potrafimy o nim opowiedzieć i posłużyć się zdobytą wiedzą w innych okolicznościach czy kontekstach. Doświadczenie staje się więc czymś w rodzaju karty przetargowej w dyskusji o prawie do wypowiedzi, komentarza czy krytyki oraz o prawie do rozstrzygania, jakie działanie związane z tym doświadczeniem jest uprawnione, a jakie nie. Nie oznacza to oczywiście, że ci, którzy tego doświadczenia nie znają, są pozbawieni prawa do wypowiedzi i projektowania odpowiednich działań. Ich komunikacyjny status jest jednak nieco inny właśnie ze względu na brak doświadczenia.

Jeśli przełożyć opisaną wyżej sytuację komunikacyjną na relacje w obszarze projektowania badań, określania ich przedmiotu oraz pozycji badawczej, okaże się, że tym, co odróżnia badaczy pełnosprawnych i niepełnosprawnych jest właśnie doświadczenie niepełnosprawności - zjawisko, którego reprezentacje literackie i, szerzej, artystyczne są przedmiotem mojego doktorskiego projektu badawczego. Z uwagi na nieobecność doświadczenia niepełnosprawności w biografii badaniom prowadzonym przez badaczy pełnosprawnych przypisywano brak autentyczności lub zarzucano wykorzystywanie cudzego doświadczenia w celu realizacji własnych naukowych ambicji i interesów ${ }^{\mathbf{1 2}}$. Doświadczenie niepełnosprawności w pewnych kontekstach stawało się więc - używając słownika filozofii różnicy, którym posługuje się Elizabeth Barnes - negatywnym markerem różnicy (negative difference-mar$k e r)^{\mathbf{1 3}}$, wprowadzającym podział i pewnego rodzaju konflikt związany z prawem własności dotyczącym jednostkowego lub zbiorowego doświadczenia. Rewersem negatywnego markera różnicy jest po prostu marker różnicy (difference-marker $)^{\mathbf{1 4}}$, czyli działanie dyskursywne, którego celem jest konstruktywne użycie różnicy jako czynnika niewprowadzającego konfliktogennego

C. Barnes, G. Mercer Breaking the Mould? An introduction to doing disability research, "Doing Disability Research" $1997 \mathrm{nr} 1$, s. 6.

3 E. Barnes Disability, Minority, and Difference, "Journal of Applied Philosophy" 2009 nr 26 (4), S. 340 .

4 Tamże, s. 338. 
podziału, ale wymagającego przepracowania różnicy w imię działania wspartego na relacjach partnerskich, sojuszniczych.

Zagadnienie dystrybucji, podziału, nadawania lub zawłaszczania prawa do dysponowania doświadczeniem niepełnosprawności stało się jednym z podstawowych tematów dyskusji oraz jednym z podstawowych elementów procesu zmiany paradygmatu naukowego w latach 9o. XX wieku w anglosaskim polu naukowym. Co ważne, dyskusje te dotyczyły obszaru społecznych badań nad niepełnosprawnością, stanowią one jednak istotne podłoże dyskursywne dla kulturowych studiów o niepełnosprawności rozwijających się jako kolejny etap krytycznego i emancypacyjnego projektu powiązania teorii i praktyki badawczej w działaniu na rzecz osób z niepełnosprawnościami i ich doświadczeń. Tym, co szczególnie interesuje mnie w przebiegu tych dyskusji i zmian sposobu prowadzenia badań naukowych, jest krytyka pasożytniczego stosunku pełnosprawnych badaczy do doświadczenia niepełnosprawności jako „przedmiotu” badań. Przywołanie tej krytyki posłuży mi do rozpoznania kolejnego ważnego mechanizmu związanego z doświadczeniem, tym razem w kontekście jego instrumentalnego wykorzystywania nie do emancypacji, tylko do utwierdzenia istniejących przekonań i postaw wobec niepełnosprawności, a także do umocnienia różnicy w jej aspekcie negatywnym.

Colin Barnes i Geof Mercer źródeł krytyki dominującego modelu badań społecznych dotyczących niepełnosprawności, opartych na pozytywistycznym z pochodzenia aksjomacie obiektywności, neutralności i bezstronności, doszukują się już w latach 6o. XX wieku. Badania społeczne stały się wówczas przedmiotem krytyki ze strony osób zaangażowanych w rozwój ruchu na rzecz praw osób z niepełnosprawnościami. Dominującym odczuciem wśród osób z niepełnosprawnością było ogólne rozczarowanie, które dotyczyło również badań naukowych nieprzynoszących wymiernych rezultatów w postaci zmniejszenia niedostępności pewnych usług lub pewnych przestrzeni, poprawy jakości życia czy zmiany negatywnych narracji na temat niepełnosprawności, na przykład narracji opierającej się na przekonaniu, że niepełnosprawność to osobista tragedia. Jedną z najsłynniejszych krytyk prowadzonych badań nad niepełnosprawnością stał się artykuł Paula Hunta - brytyjskiego aktywisty i badacza, osoby z niepełnosprawnością zatytułowany Settling Accounts with the Parasite People (1981), wymierzony przeciwko projektowi badawczemu zrealizowanemu przez Erica Millera i Geraldinę Gwynne z Tavistock Institute of Human Relations w domu pomocy Le Court Cheshire Home w Hampshire w Anglii. Badania prowadzone były w latach 70. i dotyczyły relacji i możliwości zmiany schematów współpracy 
osób niepełnosprawnych - rezydentów Le Court - z pracownikami domu i lokalnymi władzami. Co ciekawe, badania zostały zainicjowane na prośbę rezydentów i mogły zyskać formę oddolnego projektu emancypacyjnego wspieranego przez ekspertów. Wyniki przeprowadzonych badań, opublikowane w raporcie A Life Apart (1972) nie miały jednak tego emancypacyjnego waloru, ponieważ interesy rezydentów i ich uwagi wobec instytucji opiekuńczych nie zostały uwzględnione; raport podsumowujący badania był zbiorem rekomendacji dotyczących polityki opiekuńczej instytucji omijającym interesy inicjatorów projektu ${ }^{15}$. Takich badaczy, jak Miller i Gwynne, Hunt nazwał ludźmi-pasożytami (parasite people) ${ }^{16}$. Działają oni nie na korzyść zmarginalizowanych grup społecznych i nie w imię ich interesów, tylko w innych celach, a emancypacji nie traktują jako celu nadrzędnego. Ludzie-pasożyty pracują na rzecz instytucji, która zleca badania; na rzecz własnego naukowego interesu, który pozwala im na powiększanie dorobku naukowego i rozwijanie kariery; na rzecz społecznego systemu urządzenia, w którym władza porządkowania życia społeczno-politycznego należy do ekspertów reprezentujących grupę większościową, opowiadającą się za określoną normą. W tak uwarunkowanych badaniach naukowych to nie doświadczenie niepełnosprawności staje się istotne; dlatego w Wielkiej Brytanii krytyka wymierzona w badania nad niepełnosprawnością skupiła się w latach 70. na rewizji ich podstawowych założeń, wprowadzając nową epistemologiczną ramę dla naukowej i społecznej narracji na temat niepełnosprawności, jaką jest tak zwany społeczny model niepełnosprawności, przejęty i upowszechniony przez aktywistów na rzecz niepełnosprawności oraz badaczy z nurtu krytycznych studiów o niepełnosprawności (critical disability studies) i z nurtu badań emancypacyjnych w naukach społecznych (emanciparoty research) ${ }^{17}$. Część osób z niepełnosprawnościami z Le Court brała czynny udział w zawiązaniu Union of the Physically Impaired Against Segregation (UPIAS) w 1975 roku, tworząc tym samym instytucjonalne zaplecze dla działań zmierzających między innymi do zmiany naukowego podejścia do doświadczenia niepełnosprawności.

Krytyka pasożytniczej postawy badawczej formułowana przez osoby z niepełnosprawnościami, badaczy z niepełnosprawnościami oraz ich sojuszników

E. Stone, M. Priestley Parasites, pawns and partners: disability research and the role of non-disabled researchers, "British Journal of Sociology” 1996, 47 (4), s. 703.

16 Zob. P. Hunt Settling Accounts with the Parasite People - a critique of 'A Life Apart' by El Miller and GV Gwynne , Disability Challenge” $1981 \mathrm{nr}$ 1, s. 37-50. 
nie wyczerpuje się oczywiście w analizie relacji między badaczem (w latach 6o. i później zazwyczaj pełnosprawnym) a osobami z niepełnosprawnością, które uczestniczą w badaniach (ulegając de facto uprzedmiotowieniu w tym procesie). Zależało mi jednak na tym, by zwrócić uwagę na moment historyczny i kontekst, w jakim pojawia się określenie badacza jako pasożyta oraz instrumentalne traktowanie doświadczenia niepełnosprawności jako przedmiotu badań. Antagonizm między badaczem niepełnosprawności a osobą z niepełnosprawnością opierał się postrzeganiu pewnego sposobu prowadzenia badań jako groźnego dla osobistego doświadczenia niepełnosprawności, odbierającego doświadczenie ich właścicielom, niebudzącego zaufania i nierealizującego nadziei na doprowadzenie do praktycznej zmiany, która by powstrzymywała różne rodzaje zachowań dyskryminujących.

Na produkcję wiedzy o niepełnosprawności pod koniec XX wieku miało więc wpływ negatywne podłoże afektywne eksponujące różnicę w pozycji zajmowanej wobec doświadczenia niepełnosprawności (doświadczenie jako element biografii versus doświadczenie jako przedmiot badań). Ta różnica została w sposób konstruktywny krytycznie użyta do zaprojektowania nowego modelu badań społecznych, opierającego się na ustanowieniu społecznego obrazu niepełnosprawności jako podstawowej perspektywy poznawczej i etycznej. Działanie polegające na doprowadzeniu do wypracowania nowego paradygmatu naukowego badań emancypacyjnych sprawiło, że do studiów o niepełnosprawności na stałe wprowadzono takie zagadnienia, jak na przykład: relacje w polu badań, zwłaszcza te fundujące hierarchię związaną z podsiadaniem doświadczenia/wiedzy/władzy; uwarunkowania społeczne, polityczne, kulturowe oraz egzystencjalne pozycji badawczej; dostępność wiedzy i narracji naukowej dla osób, których ta narracja dotyczy; współdziałania (synergii) podmiotów zaangażowanych w tworzenie wiedzy o niepełnosprawności w celu pełnej integracji i emancypacji (zniesienia barier) oraz przekształcenia pasożytów w partnerów ${ }^{\mathbf{1 8}}$.

Przed wprowadzeniem paradygmatu krytyczno-emancypacyjnego w studiach nad niepełnosprawnością często używano kategorii doświadczenia niepełnosprawności jako określenia przedmiotu badań, co pozbawiało tę kategorię odniesienia do rzeczywistości, w której doświadczenie jest radykalnie heterogeniczne. Tego rodzaju operacja dyskursywna pojawiała się zwłaszcza w badaniach ilościowych, których efektem musiało być jakieś

18 O przekształceniu pasożytów w partnerów jako celu badań emancypacyjnych pisali m.in. E. Stone i M. Priestley w: tamże. 
uogólnienie, końcowy wniosek odnoszący się do pewnej całości, nie sytuacji jednostek. Po upowszechnieniu się postulatów ruchu na rzecz osób z niepełnosprawnościami oraz krytycznych badań o niepełnosprawności w naukach humanistycznych doświadczenie zostało - mówiąc nieco metaforycznie - zwrócone jego właścicielom lub odzyskane w wyniku działania krytyczno-emancypacyjnego. Wrażliwość krytyczna każe zapytać, kto i kiedy miałby rzekomo zwrócić to doświadczenie. Nie chodzi tu jednak o nadanie czy oddanie prawa do doświadczenia przez podmioty instytucjonalne czy badaczy niepełnosprawności (ekspertów-pasożytów lub ekspertów-partnerów), tylko o sprawiedliwy podział prawa do komunikowania o doświadczeniu niepełnosprawności w relacji partnerskiego współdziałania na rzecz integracji i emancypacji. Tego rodzaju relacje eliminowałyby antagonizm wynikający z zajmowanych pozycji wobec doświadczenia i prowadziłyby do wypracowania takich standardów postępowania badawczego, które nie naruszałoby integralności tego doświadczenia. Istotnym elementem w analizie doświadczenia niepełnosprawności jest moim zdaniem inicjujące badania określenie własnych zainteresowań naukowych i własnej pozycji jako badacza niepełnosprawności. Oba te działania pozwalają nie tylko ulokować własny projekt badawczy w tradycji nauk dotyczących niepełnosprawności, lecz także zwrócić uwagę na etyczne zobowiązania, jakie wiążą się z prowadzeniem badań krytyczno-emancypacyjnych, na oczekiwania społeczne wobec projektów naukowych poświęconych grupom mniejszościowym oraz przede wszystkim na możliwość zawiązania partnerskich relacji z podmiotami, które pojawią się w trakcie prowadzenia działań badawczych.

Ważną kwestią pozostaje również zmierzenie się z różnicą i konstruktywne, kontemplacyjne odniesienie się do niej. Kiedy pisałam o różnicy między osobami z niepełnosprawnością i niepełnosprawnymi badaczami a badaczami pełnosprawnymi, nie chodziło mi o wyeksponowanie i absolutyzowanie tej różnicy, tylko o uczynienie z niej przedmiotu namysłu w kontekście narracji o pozycji i tożsamości badawczej. Kontemplację w tym kontekście chciałabym rozumieć jako przymus powtarzania, powracania myślą do spraw i relacji, które wydają się oczywiste, neutralne, obiektywne i bezstronne. Jako sprawna badaczka niepełnosprawności, skupiająca się na reprezentacjach tego doświadczenia w narracjach, przygotowana na czekającą mnie w przyszłości operację wstawienia protezy stawu biodrowego i modyfikację manifestu autobiograficznego, będę kontemplować różnicę wynikającą z obecności lub braku doświadczenia niepełnosprawności oraz konsekwencje ustanowionych w ten sposób „perspektyw skądś”. W konstruktywnej kontemplacji 
różnicy nie chodzi jednak o zapętlenie, tylko o ruch po spirali, tak jak w procesie następowania po sobie nowych projektów krytyczno-emancypacyjnych rozwija się wiedza. Relacje między uczestnikami procesu badawczego zawsze będą istotnym tematem metadyscyplinarnym, przyczyniającym się do emancypacji (pokonywania barier) w różnych kontekstach i na różnych etapach prowadzenia praktyki badawczej.

\section{Abstract}

\section{Klaudia Muca}

JAGIELLONIAN UNIVERSITY (CRACOW)

Experience and Difference: The Subject Status and Identity of Researchers in Disability Studies

Muca discusses the position and identity of the researcher in the field of disability studies. Her critical analysis of categories and attitudes, undertaken in the spirit of the philosophy of science, and her references to the history of disability studies allow her to identify two basic categories in the position and identity of researchers: experience and difference. The experience of disability is a marker of difference, which affects relations between the actors in the research process, especially between people with and without disabilities. The difference associated with having or not having this experience has been and still is important for the development of critical and emancipatory disability studies.

\section{Keywords}

experience, difference, disability studies, researcher's position 